\title{
Plant-derived antivirals against hepatitis c virus infection
}

Ana Carolina Gomes Jardim ${ }^{1,2^{*}+}$, Jacqueline Farinha Shimizu ${ }^{1,2 \dagger}$, Paula Rahal ${ }^{2}$ and Mark Harris ${ }^{3}$

\begin{abstract}
Hepatitis C virus ( $\mathrm{HCV}$ ) infection is a worldwide public health burden and it is estimated that 185 million people are or have previously been infected worldwide. There is no effective vaccine for prevention of HCV infection; however, a number of drugs are available for the treatment of infection. The availability of direct-acting antivirals (DAAs) has dramatically improved therapeutic options for HCV genotype 1. However, the high costs and potential for development of resistance presented by existing treatment demonstrate the need for the development of more efficient new antivirals, or combination of therapies that target different stages of the viral lifecycle. Over the past decades, there has been substantial study of compounds extracted from plants that have activity against a range of microorganisms that cause human diseases. An extensive variety of natural compounds has demonstrated antiviral action worldwide, including anti-HCV activity. In this context, plant-derived compounds can provide an alternative approach to new antivirals. In this review, we aim to summarize the most promising plant-derived compounds described to have antiviral activity against HCV.
\end{abstract}

Keywords: Hepatitis C, Natural compounds, Antivirals

\section{Background}

Hepatitis $\mathrm{C}$ virus (HCV) infection is a worldwide public health burden and it is estimated that 185 million people are or have previously been infected worldwide, representing almost 3\% of the global population. Most infections persist and chronically infected individuals have a high risk to develop liver cirrhosis and hepatocellular carcinoma after 10 to 30 years of infection [1-3].

$\mathrm{HCV}$ transmission occurs by parenteral via. The main route of transmission was blood transfusion until in the 1990s when Food and Drug Administration (FDA) authorized medical centers to screen blood for HCV. Nowadays, the sharing of contaminated syringes by drug users and inadequate sterilization of medical equipment are the main transmission routes [4-6].

There is no effective vaccine for prevention of $\mathrm{HCV}$ infection, however, a number of drugs are available for

\footnotetext{
* Correspondence: jardim@ufu.br

${ }^{\dagger}$ Equal contributors

'Laboratory of Virology, Institute of Biomedical Science, ICBIM, Federal

University of Uberlândia, Avenida Amazonas, Bloco 4C - sala 216. Umuarama, Uberlândia, MG CEP: 38405-302, Brazil

${ }^{2}$ Genomics Study Laboratory, São Paulo State University, São José do Rio

Preto, SP, Brazil

Full list of author information is available at the end of the article
}

the treatment of infection. Until recently, the standard therapy was based on pegylated interferon (IFN) plus ribavirin (RBV), resulting in a sustained virological response in approximately $50 \%$ of patients infected with HCV genotypes $1 \mathrm{a} / 1 \mathrm{~b}$ and $80 \%$ of those infected with genotypes 2 or 3 [7-9]. The availability of new, directacting antivirals (DAAs) targeting the NS3/4A protease, NS5B polymerase and NS5A protein have dramatically improved therapeutic options for HCV genotype 1 [10, 11]. However, the high costs and potential for development of resistance presented by existing treatment demonstrate the need for the development of more efficient new antivirals, or combination of therapies that target different stages of the viral lifecycle. The efforts to develop innovative anti-HCV drugs are challenged by the viral high mutation rate, which allows the rapid emergence of resistant strains to DAAs directed to the NS5A and NS3 regions. Further issues to overcome include the development of a drug which can impair the virus with limited side effects on the host cell and the affordable access to care in developing countries.

Over the past decades, there has been substantial study of compounds extracted from plants that have activity against a range of microorganisms that cause 
human diseases. Natural compounds have received increasing attention for their therapeutic potential, including antiviral properties $[12,13]$. An extensive variety of natural compounds has demonstrated either antiviral action worldwide, including anti-HCV activity [2, 12-14], or hepatoprotective effect as described for naringenin, (-)-epigallocatechin-3-gallate (EGCG), silymarin and caffeine [15-18].

In this context, plant-derived compounds can provide an alternative approach to new antivirals. Natural compounds present characteristics such as high chemical diversity, lower cost of production and milder or inexistent side effects than conventional treatment [19]. Additionally, most of the drugs used today in the clinic were first discovered from plants and microorganisms [20-22]. In this review, we aim to summarize the most promising plant-derived compounds described to have antiviral activity against $\mathrm{HCV}$.

\section{The HCV replication cycle}

$\mathrm{HCV}$ is a small, enveloped virus, grouped within the genus Hepacivirus of the Flaviviridae family [23]. Its singlestrand positive genomic RNA of $9600 \mathrm{~kb}$ in length has a single open reading frame, with untranslated regions (UTR) in both 5' and 3' ends. These UTR regions are well conserved RNA structures essential for the translation of viral proteins and viral genome replication $[24,25]$.

The HCV viral particles are associated with low density lipoproteins (LDL) and very low-density lipoproteins (VLDL) and this association is related to infectivity. Virions circulate in the blood-stream of patients as lipoviroparticles [26-28]. The first stage of HCV infection is the attachment of virus particles on the surface of the host cell followed by the specific interaction of the viral envelope glycoproteins E1 and E2 with cellular receptor molecules, such as the tetraspanin CD81, scavenger receptor class B type 1 (SRB1), and the tight junction components claudin 1 (CLDN1) and occludin (OCLN) [29]. HCV entry into the host cells by clathrin-mediated endocytosis [30]. The viral RNA is released into the cytoplasm after the uncoating of the nucleocapsid and is translated at the rough endoplasmic reticulum (ER) under the control of the viral internal ribosome entry site (IRES) giving rise to a single polyprotein which is co- and posttranslationally cleaved into 10 proteins: the structural proteins core and envelope glycoproteins E1 and E2, the viroporin $\mathrm{p} 7$ and the nonsctructural proteins NS2, NS3, NS4A, NS4B, NS5A and NS5B [31, 32]. To process HCV structural proteins a minimum of two cellular peptidases are required, while the non-structural proteins are cleaved by viral peptidases [33]. The non-structural viral proteins NS3/4A, NS4B, NS5A and NS5B assemble and interact with host proteins to form the virus replication complexes that will amplify viral RNA via the prior synthesis of negative strand intermediates. HCV replication occurs in the host cell cytoplasm in a specialized membranous compartment from the endoplasmic reticulum, termed the membranous web. To form this compartment, viral proteins induce a rearrangement of the ER membranes [34-36]. Host proteins as cyclophilin A, VLDL/LDL pathways and mRNA122 seem to be associated with the improvement of $\mathrm{HCV}$ replication cycle $[28,37]$. The assembly of new viral particles occurs in close vicinity to lipid droplets and the core protein interacts with NS5A to recruit nascent genomes. Apolipoprotein $\mathrm{E}$ also seems to be essential to the formation of lipoviroparticles [27, 38-41] and modifications observed in E1 and E2 proteins of virions indicate that these proteins are processed by Golgi complex [42].

\section{Plant-derived compounds with anti-hcv properties Blockade of HCV entry}

Viral entry is an attractive point of intervention to prevent virion access into non-infected cells. This multistep process can be inhibited by small molecules, including compounds extracted from natural sources that have shown to abrogate HCV infectivity. Unlike for example HIV, no entry inhibitor has been licensed for the treatment of $\mathrm{HCV}$ infected patients. Efficient inhibition of this stage of virus life cycle can play an important role in a future combined therapy which could include compounds with different targets and modes of action.

The blockade of HCV entry by the proteins griffithsin (GRFT) and scytovirin (SVN) originally isolated from red [43] and blue-green algae [44], respectively, was reported by Takebe et al. [45]. By their unique structural characteristics, these proteins are able to bind to multiple carbohydrate moieties [46-48] and demonstrated to inhibit HCV in both cell culture and pseudoparticle assays by targeting HCV envelope glycoproteins E1 and E2. The authors first observed an effect of these proteins using a replicon assay system and a potent activity against $\mathrm{HCV}$ in a cell-based assay with JFH-1 virus (SVN EC50 $17 \mathrm{nM}$, GRFT EC50 $0.4 \mathrm{nM} ; \mathrm{CC} 50=34 \mathrm{mM}$ and a selectivity index (SI) of $84,000)$. The results were expanded upon utilizing chimeras encompassing the E1 and E2 proteins from the $\mathrm{HCV} 2 \mathrm{a}$ isolate $\mathrm{J} 6$ or the $\mathrm{HCV} 1 \mathrm{~b}$ isolate $\mathrm{TH}$, showing that multiple viral isolates were sensitive to both GRFT and SVN. Further, by using HCV pseudoparticle assay bearing $\mathrm{E} 1$ and $\mathrm{E} 2$ proteins from the $\mathrm{HCV} 2 \mathrm{a}$ isolate $\mathrm{J} 6$ and the HCV $1 b$ isolate TH, they demonstrated that GRFT (EC50's ranging from $0.3-14.1 \mathrm{nM}$ ) and SVN (EC50's ranging from 3.2-96 $\mathrm{nM}$ ) acted early in the viral lifecycle, inhibiting all three $\mathrm{HCV}$ isolates. They were able to demonstrate that these proteins activity on $\mathrm{HCV}$ entry was explained by their targeting of high-mannose oligosaccharides on either E1 or E2, but did not inhibit binding of E2 to CD81. In addition, they showed that GRFT was active in an albumin-urokinase plasminogen activator/severe combined 
immunodeficient chimeric mouse model of $\mathrm{HCV}$ infection with up to a $2.5-\log$ reduction of viral titers. The authors also tested GRFT in vivo by using a transgenic mouse model. The dose of $20 \mathrm{mg} / \mathrm{kg} /$ day of GRFT was administered for a total of 18 days and at the end of the experiment a reduction of $\sim 2.7 \log$ in HCV levels was observed in serum.

Recently, a study which evaluated the anti-HCV properties of Limonium sinense extracts demonstrated that an aqueous extract from the underground part of the plant (LS-UW) potently inhibited HCV early entry events by impairing virus attachment and entry/fusion without affecting viral replication, translation and cell-to-cell propagation [49]. They evaluated the bioactive molecules in LS-UW that could contribute to its anti-HCV effect and identified gallic acid (GA) as the compound which most inhibited HCVcc infection $\quad(E C 50=24.31 \pm 6.90 \mu \mathrm{M} ; \quad C C 50=346.59 \pm$ $27.44 \mu \mathrm{M} ; \mathrm{SI}=14.25)$. GA also targeted early viral entry, specifically inactivating cell-free virions and blocking virus binding to the host cell surface, with little effect against the post-binding viral entry/fusion, showing that further compounds may be acting on this stage. Additionally, interaction(s) between constituents could result in synergistic effects to exert anti-HCV efficacy observed by treatment with LS-UW. The authors demonstrated that both LS-UW and GA could also suppress HCV infection of primary human hepatocytes. However, the specific mechanisms by which LS-UW and GA act was not clarified.

The inhibition of early steps of HCV life cycle was also observed by the treatment of $\mathrm{HuH} 7.5$ cells infected with Gaussia luciferase reporter viruses (Jc1-GLuc) with a saponin-rich methanolic extract of Bupleurum kaoi roots (BK) or its associated saikosaponins SSa, SSb2, SSc, and SSd [50]. Bupleurum spp. roots (Radix Bupleuri) are frequently used as herbal treatments for liver diseases and saikosaponins showed to attenuate liver fibrosis [51]. By adding compounds at different times to the infectious HCV culture system Lin et al. demonstrated that SSb2 at $50 \mu \mathrm{M}$ was able to block infection by neutralizing free virus particles and abolishing viral attachment and entry/fusion. In contrast, BK $(50 \mu \mathrm{M})$ and SSa $(8 \mu \mathrm{M})$ appeared to be most effective during the entry/fusion event [50]. The molecular mechanism of action of SSb2 is related to the antiviral effect of this compound on HCV glycoproteins during the initial stages of infection. The pan-genotypic antiviral activity was also demonstrated using chimeric HCV particles from genotypes 2b (J8/JFH1), 3a (S52/ $\mathrm{JFH} 1)$, and 7a (QC69/JFH1), and clinical HCV isolates of different genotypes. These data provide evidence that SSb2 may act as an efficient inhibitor of HCV viral entry in vitro.

Haid et al. screened a library of natural phenolic compounds isolated from extracts of Marrubium peregrinum $L$ (Lamiaceae) for their anti-HCV activity [52]. By using the highly permissive human hepatoma cell line Huh7-
Lunet/CD81 with firefly luciferase reporter viruses based on the intragenotypic genotype $2 \mathrm{a}$ chimera Jc1, they identified an active extract. Ladanein was the dominant flavonoid and demonstrated to possess the antiviral activity by treatment of cells with natural or synthesized compound (BJ486K) that was based on the natural chemical structure. Natural ladanein and BJ486K inhibited a postattachment entry step, but not RNA replication or assembly. BJ486K, similar to CD81-specific antibody used as one of the HCV entry control inhibitors, was active not only during $\mathrm{HCV}$ inoculation but also after virus binding, it was shown to be effective against all major $\mathrm{HCV}$ genotypes (1a, 1b, 2b, 3a, 4a, 5a, and 6a) with an $\mathrm{EC}_{50}$ $\leq 4.2 \mu \mathrm{M}$, including a variant (mutation G451R within the HCV envelope protein E2) [53] that is resistant to the entry inhibitor ITX5061 by reducing viral dependency on SR-BI-receptor [54], indicating that it inhibits HCV cell entry independently of viral genotype/subtype. The antiviral activity of BJ486k was also demonstrated in primary human hepatocytes in a dose dependent manner with an $\mathrm{EC}_{50}$ of approximately $10 \mu \mathrm{mol} / \mathrm{L}$. Additionally, combined administration of BJ486K and cyclosporine A showed a synergistic effect in inhibition of HCV infection. The oral bioavailability of BJ486K was stablished in mice, with plasma level of $329 \mathrm{nmol} / \mathrm{L}$ after a single oral dose of $0.25 \mathrm{mg} / \mathrm{kg}$. However, the effects of BJ486K against $\mathrm{HCV}$ in vivo have not been tested [52].

Delphinidin, a polyphenol plant pigment that gives a blue-purple color to flowers and berries, was reported as an entry inhibitor against all HCV genotypes [55]. Delphinidin exhibited strong inhibition of infection $\left(\mathrm{EC}_{50}\right.$ of $3.7 \pm$ $0.8 \mu \mathrm{M})$, The effects of delphinidin were evaluated by adding the compound to the cells prior to, during and after infection. However, the antiviral activity was only observed during infection, suggesting an activity of delphinidin on the virus particle. The results of a binding assay demonstrated that delphinidin reduced HCV attachment by decreasing the amount of $\mathrm{HCV}$ RNA bound to the cell surface. However, delphinidin had no effect on virus aggregation or disrupted the envelope of virus particle. The authors also investigated whether delphinidin affected the morphology of virus particle by incubating HCVpp (genotype 2a) with delphinidin or controls and cryoTEM analysis. They demonstrated that this polyphenol acts on E1 and E2 glycoproteins inducing conformational changes on the viral particles, affecting interaction between the viral particles and cell surface.

\section{Interference with HCV replication}

Inhibiting $\mathrm{HCV}$ replication by blocking the synthesis of newly viral genomes is a promising strategy for the development of new antivirals. Targeting this step of $\mathrm{HCV}$ life cycle specifically abrogates the production of viral genomes in HCV infected cells. 
The inhibition of HCV replication by plant-derived compounds was previously described. In 2014, Choi et al. reported that xanthone compounds identified within ethanol extract from mangosteen frit peels (MG-EtOH) suppressed HCV replication [56]. Garcinia mangostana L., commonly known as Mangosteen, belongs to the Clusiaceae family and is cultivated manly in Indonesia, Malaysia, Philippines and Thailand. MG-EtOH was able to block HCV genome replication by reducing both protein and RNA levels in infectious replicon systems of genotypes $1 \mathrm{~b}\left(\mathrm{EC}_{50} 5.1 \mu \mathrm{g} / \mathrm{mL}\right)$ and $2 \mathrm{a}\left(\mathrm{EC}_{50} 3.8 \mu \mathrm{g} / \mathrm{mL}\right)$. An additive effect of MG-EtOH and the NS5A inhibitor daclatasvir [57] was also confirmed [56]. It was also shown that MG-EtOH had a modest inhibitory effect on NS5B in vitro and was able to restore the increasing levels of reactive oxygen stress (ROS) production by $\mathrm{HCV}$ infection to normal levels. $\alpha$ - and $\beta$-mangostins $\left(\mathrm{EC}_{50} 6.3 \mu \mathrm{g} / \mathrm{mL}\right.$ and $2.7 \mu \mathrm{g} / \mathrm{mL}$ ) were known to be the molecules responsible for inhibitory effect on $\mathrm{HCV}$.

The reduction of protein and RNA levels was also shown by the treatment of subgenomic replicon harbouring cells with 3-hydroxy caruilignan C (3-HCL-C) isolated from Swietenia macrophylla stems, from the Meliaceae family, used as a folk medicine in Malaysia. 3-HCL-C exhibited high anti-HCV activity at nontoxic concentrations, with an EC50 value of $10.5 \pm 1.2 \mu \mathrm{M}$. Additionally, combinations of 3-HCL-C and interferon- $\alpha$ (IFN- $\alpha$ ), HCV NS5B polymerase inhibitor (2'-C-methylcytidine; NM-107) or an HCV NS3/4A protease inhibitor (Telaprevir; VX-950) increased the suppression of HCV RNA replication. The mechanism by which 3-HCL-C interfered with HCV replication was shown to involve induction of IFN-stimulated response element transcription and IFN-dependent antiviral gene expression [58].

Plumbagin (5-hydroxy-2-methyl-1,4-naphthoquinone) is mainly found in roots of Plumbago indica L., a plant of the Plumbaginaceae family. Plumbagin has demonstrated several biological activities including anticancer [59], antiinflammatory and antimicrobial [60]. Hassan et al. reported a dose-dependent effect of plumbagin on HCV lifecycle by the infection of Huh-7.5 cells with the full-length HCV FL-J6/JFH/JC1 for $6 \mathrm{~h}$ and treatment with plumbagin for $96 \mathrm{~h}$. The intracellular HCV RNA was quantified by real-time PCR and plumbagin demonstrated an IC50 value of $0.57 \mu \mathrm{M} / \mathrm{L}$ and $\mathrm{SI}=53.7$ [61]. The authors analyzed the expression of non-structural protein NS3 of $\mathrm{HCV}$ and the cellular protein hA3G, a cytidine deaminase that was described as a host factor with anti-HCV activity [62]. Results demonstrated that plumbagin increased the expression of hA3G protein and decreased NS3 protein expression in a dose-dependent manner.

Xanthohumol $(\mathrm{XN})$ is the main prenylated chalcone present in hops (Humulus L., Cannabaceae) [63, 64]. This natural product has been shown to possess biological properties including anticancer [65], anti-inflammatory [66, 67] and antiviral activities [68-70]. Lou et al. demonstrated that $\mathrm{XN}$ at 7.05 or $14.11 \mu \mathrm{M}$ achieved an inhibitory effect on $\mathrm{HCV}$ replication in vitro similar to that of IFN $-\alpha 2 b$ by measuring luciferase activity and RNA levels in Huh7.5 cells infected with J6-JFH1 isolate of HCV [71]. The mode of action of $\mathrm{XN}$ on $\mathrm{HCV}$ infection remains to be elucidated. However, author suggested that $\mathrm{XN}$ may act as a hosttargeting inhibitor by affecting the triglyceride-synthesizing enzyme diacyglycerol acyltransferase-1 (DGAT1) expression or/and the microsomal triglyceride transfer protein (MTP) activity, based on previous evidence [72-74]. Yang and coworkers administrated $10 \mathrm{mg} / \mathrm{ml}$ of XN in Tupaia belangeri infected with $\mathrm{HCV}$. The $\mathrm{XN}$ was divided into 3 doses and given to the animals by gavage three times a day for 12 weeks. The results demonstrated a decrease in liver damage and modulates oxidative reaction and apoptosis in animals treated with $\mathrm{XN}$ [75].

The flavonoid Apigenin, which is present in many fruits and vegetables, also has diverse biological effects, including improvement of the cancer cell response to chemotherapy [76], tumorigenesis [77, 78], modulating immune cell function [79], and anti-platelet activity [80]. Apigenin is also demonstrated to have inhibitory effect on the maturation of a subset of miRNAs and on the subsequent miRNA functions [81]. MicroRNA122 (miR122), abundantly expressed in the liver and essential for the HCV RNA stability and propagation, positively regulates $\mathrm{HCV}$ replication through binding to the 5'-UTR of the HCV genome [82, 83]. In 2014, Shibata et al. demonstrated that $5 \mu \mathrm{M}$ of Apigenin inhibited HCV replication in vitro without affecting cell growth or viability. The inhibitory effect of apigenin on HCV replication was possibly explained by decreasing the levels of mature miR122 through the inhibition of the phosphorylation of TRBP, a component of miRNA-generating complexes via impaired mitogenactivated protein kinase activation [84].

Coffee intake has been associated with lower rates of liver disease progression in chronically $\mathrm{HCV}$ infected patients [85]. Several compounds extracted from coffee, including caffeine, may have beneficial effects on the liver [86-88]. Caffeine has been demonstrated to have an antiproliferative effect on liver cancer cells [89], may limit liver fibrosis [90] and interact with cellular pathways to slow the progression of liver diseases [91]. The effects of caffeine on HCV replication was evaluated in 2015 by Batista et al. by using a cell line stably harbouring the SGR-Feo JFH-1 and by infecting Huh-7.5 cells with J6/ JFH1 HCV isolate [92]. Caffeine efficiently inhibited $\mathrm{HCV}$ replication in a dose dependent manner and reducing HCV RNA levels and protein expression by up to $80 \%$ of the non-treated control at the highest safely tolerated concentration $(2 \mathrm{mM})$. The half-maximal inhibitory concentration $\left(\mathrm{IC}_{50}\right)$ was reported to be in order of $0.726 \mathrm{mM}$. The authors demonstrated that cell cycle 
progression pattern and apoptosis levels remained unchanged in caffeine treated cells. Induction of autophagy was also investigated but no significant difference was found apart from a higher proportion of cells in an autophagic state observed in the presence of caffeine.

Compounds extracted from Brazilian plants also showed to dramatically inhibit $\mathrm{HCV}$ replication in vitro. The compounds APS $\left(\mathrm{EC}_{50}=2.3 \mu \mathrm{M}\right)$, a natural alkaloid isolated from Maytrenus ilicifolia, the tetrahydrofuran lignans $3 * 43$ $\left(\mathrm{EC}_{50}=4.0 \mu \mathrm{M}\right)$ and $3 * 20\left(\mathrm{EC}_{50}=8.2 \mu \mathrm{M}\right)$ and the secolignan 5*362 $\left(\mathrm{EC}_{50}=38.9 \mu \mathrm{M}\right)$ from Peperomia blanda were tested by their inhibitory effects on HCV replication using either subgenomic reporter SGR-Feo-JFH1 and the full-length Rluc-J6/JFH1. Data demonstrated that by treatment with these compounds dramatically reduced $\mathrm{HCV}$ RNA and protein levels and acted mainly by preventing the formation of new replication complexes [93]. It was also shown that replication blockade by Brazilian naturally occurring compounds was independent of $\mathrm{HCV}$ genotype and was not affected by variants described to confer resistance to the NS5A targeting compound daclatasvir [57, 94, 95]. At the same work, a natural kavalactone $F 8^{*} 40$ isolated from Piper fuligineum, showed a significant but not dramatic effect on IRES-directed translation, correlated with a reduction of protein levels in the presence of this compound, suggesting that its mode of action is related to the inhibition of IRES-mediated translation [93].

The effect on baseline IRES translation was earlier showed by treating of cells with quercetin, a plant-derived flavonoid present in fruits, vegetables, leaves and grains [96]. The inhibition of HCV replication by quercetin was first demonstrated by Gonzalez et al. in 2009 [97]. These researchers sought to identify interaction between $\mathrm{HCV}$ NS5A and cellular protein that could play a role in the virus production. By co-immunoprecipitation and colocalization assays they detected interactions between NS5A and the heat shock proteins (HSP) HSP40 and HSP70. Using a transient transfection luciferase-based tissue culture system, the authors demonstrated that treatment with quercetin, an inhibitor of HSP synthesis, markedly reduced HCV IRES activity and its increase by NS5A. However, quercetin was found to decrease IRES activity either in absence or in presence of NS5A. Quercetin treatment $(50 \mu \mathrm{M})$ did not reduce viral genome copy numbers but NS5A protein levels and had strongly inhibited $\mathrm{HCV}$ production in cell culture. RNA replication of SGR -harboring cells was not affected by treatment, supporting that the major role of HSP40 and HSP70 may not be in genome replication but rather in subsequent stages in the viral life cycle. Additionally, the effects of quercetin could be related to a global reduction in most of the HSP family members, not restricted to the HSP40 and HSP70, as siRNA-mediated depletion of HSP proteins had no effect on HCV particle production.
Later in 2012, the same research group further investigated the mode of action of quercetin and other structurally related bioflavonoids [98]. Using a HCV IRES bicistronic reporter assay system, they showed that the translation inhibitory effect of quercetin treatment was NS5A dependent, consistent with the mechanism of NS5A/HSP7 complexdriven IRES-mediated translation of viral proteins. They also demonstrated that quercetin had a lesser effect on intracellular infectious virus assembly and had no effect on virion secretion. Furthermore, quercetin had a strong inhibitory effect on HSP70 expression, supporting the conclusion that bioflavonoids mediate their antiviral effects at least in part by blocking HSP expression and underscore the role of HSPs in HCV life cycle.

Also in 2012, Bachmetov et al. identified quercetin as the active substance responsible for the inhibition of NS3 protease activity by Embelia ribes plant extracts [99]. They showed that it was found to inhibit NS3 activity in a specific dose-dependent manner in an in vitro catalysis assay. Using a model system in which NS3 engineered substrates were introduced into NS3-expressing cells, they demonstrated that quercetin-mediated inhibition could be explained by an NS3 protease specific mechanism. This inhibition of NS3 was confirmed in cell culture with NS3 protease-dependent fluorescent reporter systems. They also demonstrated that quercetin at $10 \mu \mathrm{g} / \mathrm{mL}$ inhibited HCV RNA replication up to $70 \%$ as analysed in the SGR system, as well as the HCV infectious virus production by treating cells infected with intergenotype HJ3-5 chimeric virus up to $95 \%$. Taking all data available, these authors suggested that the high inhibition efficiency of virus production could be attributed to a mutual inhibitory effect of quercetin targeting both NS3 protease and NS5A.

In addition to these described inhibitory mechanism, Pisonero-Vaquero et al. investigated in 2014 the contribution of oxidative/nitrosative stress (ROS/SNS) and lipid metabolism modulation in the inhibition of $\mathrm{HCV}$ replication by quercetin [100]. They showed that quercetin inhibited HCV replication in Huh7 cells expressing full-length genotype $1 \mathrm{~b} \mathrm{HCV}$ replicon in a dose-dependent manner alone (up to $61 \%, 5 \mu \mathrm{M}$ ), or combined with IFN $\alpha$ (up to $72 \%$, $5 \mu \mathrm{M}$ ), and HCV NS5A and core protein expression was also reduced (up to $78 \%, 5 \mu \mathrm{M}$ ). Quercetin acted by decreasing $\mathrm{HCV}$-induced ROS/RNS generation (up to $35 \%$, $5 \mu \mathrm{M}$ ) and lipoperoxidation (up to $30 \%, 5 \mu \mathrm{M}$ ) in replicating cells. The treatment significantly decreased HCVinduced intracellular lipid accumulation in a dosedependent manner (Q5: 55\% vs HCV-G1 vehicle-treated cells), inhibited liver X receptor (LXR)a-induced lipid accumulation in LXRa-overexpressing and replicon-containing Huh7 cells (Q5: 34\% vs HCV-G1 vehicle-treated cells). Inactivation of phosphatidylinositol 3-kinase (PI3K)/AKT pathway was inferred to be the mechanism involved in 
modulating LXRa-dependent lipogenesis by quercetin and may contribute to the inhibition of viral replication.

An additional anti-HCV activity by quercetin-based treatment was recently suggested [101]. Lulu et al. predicted the 3D structure HCV NS2 protein and performed docking studies to identify phytochemical compounds which could have strong affinity towards its protease. Ten plants-derived compounds were tested and quercetin revealed minimum binding energy of $7.95 \mathrm{kcal} / \mathrm{mol}$ with NS2, demonstrating the theoretical potential of this compounds to target HCV NS2 protease.

The inhibitor activity of NS3/4A protease was also shown by testing triterpenes from Cynomorium songaricium [102]. "SuoYang" (Cynomorium songaricum Rupr; Cynomoriaceae) is a parasitic plant, which grows mainly in the northern part of China, such as Inner Mongolia Autonomous Region and Gan Su Province. Using an $\mathrm{HCV}$ protease assay it was shown that malonyl ursolic acid hemiester tested triterpen was the most potent inhibitor of NS3/4A in this free-cells method.

\section{Assembly and release}

Naringenin is a dietary supplement derived from naringin, one of the most abundant flavonoids in citrus fruits. It has been demonstrated to possess anti-oxidant, antiinflammatory, anti-carcinogenic properties, and also to reduce cholesterol levels both in vitro and in vivo [103-107]. Grapefruit's bitter taste is caused by the presence of naringin, which is metabolized into naringenin. It was previously demonstrated that Naringenin, or its glycosylated form, can reduce cholesterol levels in animals and in human cells both in vivo and in vitro $[108,109]$.

In 2008, Nahmias et al. demonstrated a dose-dependent inhibitory effect of naringenin on HCV release [74]. The authors treated infected Huh-7.5.1 cell with naringenin for $24 \mathrm{~h}$, supernatant was collected, cells were harvested and HCV RNA was measured by qRT-PCR. The results showed a decrease of $\mathrm{HCV}$ core secretion and extracellular $\mathrm{HCV}$ positive strand RNA, demonstrating that naringenin at the concentration of $200 \mu \mathrm{M}$ could inhibit up to $80 \% \mathrm{HCV}$ secretion. Later, Goldwasser et al. related that naringenin was able to block the assembly of intracellular HCV particles [110]. The authors suggested that the mode of action of naringenin could be the PPAR $\alpha$ activation. PPAR $\alpha$ is a transcription factor associated with lipid metabolism in the liver, related to the reduction of lipogenesis and VLDL secretion [111], and these mechanisms are extremely related to $\mathrm{HCV}$ infectivity due to affect the viral assembly. By treating Huh7.5.1 cells infected with JFH1 virus with $200 \mu \mathrm{M}$ naringenin or $10 \mu \mathrm{M}$ of a classical PPAR $\alpha$ agonist (WY14643), they were able to demonstrate that naringenin or WY14643 caused an inhibition of HCV RNA secretion and did not affect the intracellular levels of HCV RNA. Naringenin was also co-incubated with WY14643 and no increased effect was observed, demonstrating the possible effect of naringenin in PPAR $\alpha$ activation. More recently, Lulu et al. analysed by molecular docking studies the structural interactions between naringenin and the protein NS2 protease [101]. They demonstrated that naringenin exhibited a lower minimum binding energy $(-7.97 \mathrm{kcal} / \mathrm{mol})$ than $\mathrm{RBV}(-5.89 \mathrm{kcal} / \mathrm{mol})$ to bind to NS2 protein, suggesting that naringenin requests a lesser amount of energy to disrupt HCV NS2 protein. These results demonstrated a theoretical potential of naringenin as an inhibitor of HCV NS2 protease [112]. However, this data has not been confirmed by in vitro or in vivo assays yet.

\section{Broad spectrum activity against $\mathrm{HCV}$}

Honokiol, a lignan isolated from leaves of Magnolia officiais, was shown to have multiple effects on $\mathrm{HCV}$ infection, strongly inhibiting $\mathrm{HCV}$ infection $\left(\mathrm{EC}_{50} 1.2 \mu \mathrm{M}\right)$ in both the J6/JFH1 reporter virus system (p7-Rluc2A) and in a pseudoparticles system containing glycoprotein of three different HCV genotypes (1a, 1b and 2a) [100-102]. The mechanism in which honokiol affects HCV entry was reported by Lan et al. [113]. The treatment of cells with this natural compound suppressed the OCLN and SR-BI receptors involved in $\mathrm{HCV}$ infection. The authors also demonstrated that honokiol was able to inhibit HCV IRES-mediated translation. However, this antiviral action was observed only at the highest concentration treatment $(30 \mu \mathrm{M})$ and no effect was detected at concentration lower than $20 \mu \mathrm{M}$. Honokiol was also effective against $\mathrm{HCV}$ replication as observed against two SGR, the genotype 1b (pFK-I389luc-NS3-3'/5.1) and genotype 2a (pSGR-Fluc-JFH1).

Oxymatrine and matrine are the two major alkaloids in the aqueous extract from the Sophora root. Oxymatrine is reported to have antiviral activity against $\mathrm{HCV}$ in cell cultures and has shown hepatoprotective activity in an animal study [114-116]. In a clinical perspective, the components oxymatrine and matrine found in Sophora roots have shown to reduce viral load and liver fibrosis $[19,117]$. Mao et al. evaluated the efficacy and safety of oxymatrine for the treatment of hepatic fibrosis in patients with chronic viral hepatitis B or C. Patients took three doses of $300 \mathrm{mg}$ oxymatrine a day for 52 weeks. The data obtained demonstrated a decrease of alanine aminotransferase (ALT) and histological inflammatory activity decreased from 46.08 ( \pm $3.84)$ to $4.00( \pm 2.97)$ after treatment with oximatrine based on Semi-quantitative scoring system [118].

Epigallocatechin-3-gallate is the major component in green tea. This polyphenol belongs to the Flavonoid family and is reported with antiviral activity against a range of viruses such as Chikungunya virus [119], Enterovirus-71 [120] and HCV $[55,121]$ in addition to other activities as anti-inflammatory and antioxidative [122] anti-cancer [123]. EGCG was initially described by Ciesek et al. as an inhibitor of HCV entry and cell to cell spread. The inhibition of $\mathrm{HCV}$ entry was confirmed by incubating EGCG 
Table 1 Plant-derived antivirals tested in cellular models with activity against HCV life cycle. Structures from PubChem (https:// pubchem.ncbi.nlm.nih.gov)

\begin{tabular}{|c|c|c|c|c|c|c|c|}
\hline Compound & Structure & Extracted from & $\begin{array}{l}\text { Viral Inhibition } \\
\text { step }\end{array}$ & $\begin{array}{l}\text { HCV } \\
\text { genotypes }\end{array}$ & EC50 & CC50 & Reference \\
\hline Griffithsin & & Griffithsia sp & Entry & $1 b, 2 a$ & $0.4 \mathrm{nM}$ & $33.6 \mu \mathrm{M}$ & {$[45]$} \\
\hline Scytovirin & & Scytonema varium & Entry & $1 b, 2 a$ & $17 \mathrm{nM}$ & $23.8 \mu \mathrm{M}$ & {$[45]$} \\
\hline Gallic Acid & & Limonium sinense & Entry & $2 \mathrm{a}$ & $24.31 \pm 6.90 \mu \mathrm{M}$ & $346.59 \pm 27.43 \mu \mathrm{M}$ & \\
\hline Saikosaponin b2 & & Bupleurum kao & Entry & $2 b, 3 a, 7 a$ & $16.13 \pm 2.41 \mu \mathrm{M}$ & $740.4 \pm 28.35 \mu \mathrm{M}$ & \\
\hline Ladanein & & $\begin{array}{l}\text { Marrubium } \\
\text { peregrinum L }\end{array}$ & Entry & $\begin{array}{l}1 a, 1 b, 2 b \\
3 a, 4 a, 5 a, 6 a\end{array}$ & $\leq 2.54 \mu \mathrm{mol} / \mathrm{L}$ & $98.04 \mu \mathrm{mol} / \mathrm{L}$ & {$[52]$} \\
\hline Delphinidin & & Anthocyanidin & Entry & $1 a, 2 a$ & $3.7 \pm 0.8 \mu \mathrm{M}$ & - & {$[55]$} \\
\hline Epigallocatechin-3-gallate & & Camellia sinensis & $\begin{array}{l}\text { Entry/ } \\
\text { Replication }\end{array}$ & $\begin{array}{l}1 a, 2 a \\
2 a \\
1 b, 2 a\end{array}$ & $\begin{array}{l}10.6 \pm 2.9 \mu \mathrm{M} \\
2.5 \mu \mathrm{g} / \mathrm{mL} \\
17.9 \mu \mathrm{M}\end{array}$ & $232.6 \mu \mathrm{M}$ & $\begin{array}{l}{[121]} \\
{[125]} \\
{[123]}\end{array}$ \\
\hline Xanthone extract & - & $\begin{array}{l}\text { Garcinia } \\
\text { mangostana L. }\end{array}$ & Replication & $\begin{array}{l}1 \mathrm{~b} \\
2 \mathrm{a}\end{array}$ & $\begin{array}{l}5.1 \mu \mathrm{g} / \mathrm{mL} \\
3.8 \mu \mathrm{g} / \mathrm{mL}\end{array}$ & $12.8 \mu \mathrm{g} / \mathrm{mL}$ & {$[56]$} \\
\hline 3-hydroxy caruilignan C & & $\begin{array}{l}\text { Swietenia } \\
\text { macrophylla }\end{array}$ & Replication & $1 b$ & $10.5 \pm 1.2 \mu \mathrm{M}$ & - & {$[58]$} \\
\hline Plumbagin & & Plumbago indica L. & Replication & $2 a$ & $0.57 \mu \mathrm{M}$ & $30.65 \pm 1.25 \mu \mathrm{M} / \mathrm{L}$ & {$[61]$} \\
\hline Xanthohumol & & Humulus $L$. & Replication & $2 a$ & - & - & [71] \\
\hline Apigenin & & Flavone & Replication & $2 \mathrm{a}$ & - & - & [84] \\
\hline Caffeine & & Alkaloid & Replication & $2 a$ & $0.726 \mathrm{mM}$ & - & [92] \\
\hline
\end{tabular}


Table 1 Plant-derived antivirals tested in cellular models with activity against HCV life cycle. Structures from PubChem (https:// pubchem.ncbi.nlm.nih.gov) (Continued)

\begin{tabular}{|c|c|c|c|c|c|c|c|}
\hline Compound & Structure & Extracted from & $\begin{array}{l}\text { Viral Inhibition } \\
\text { step }\end{array}$ & $\begin{array}{l}\text { HCV } \\
\text { genotypes }\end{array}$ & EC50 & CC50 & Reference \\
\hline$\overline{\text { APS }}$ & & Maytrenus ilicifolia & Replication & $2 a$ & $2.3 \mu \mathrm{M}$ & $135.24 \mu \mathrm{M}$ & [93] \\
\hline $3 * 43$ & & & & & $4.0 \mu \mathrm{M}$ & $18.8 \mu \mathrm{M}$ & \\
\hline $3^{*} 20$ & & & & & $8.2 \mu \mathrm{M}$ & $32.8 \mu \mathrm{M}$ & \\
\hline $5 * 362$ & & Peperomia bland & Replication & $2 \mathrm{a}$ & $38.9 \mu \mathrm{M}$ & $73.91 \mu \mathrm{M}$ & \\
\hline Quercetin & & Embelia ribes & Replication & $\begin{array}{l}1 a, 2 a \\
1 b\end{array}$ & - & - & $\begin{array}{l}{[99]} \\
{[100]}\end{array}$ \\
\hline Ursolic acid & & $\begin{array}{l}\text { Cynomorium } \\
\text { songaricium }\end{array}$ & Replication & - & $16 \mu \mathrm{g} / \mathrm{mL}$ & - & [102] \\
\hline Acetyl ursolic acid & & & & & $11 \mu \mathrm{g} / \mathrm{mL}$ & - & \\
\hline $\begin{array}{l}\text { Malonyl ursolic } \\
\text { acid hemi- ester }\end{array}$ & & & & & $8 \mu \mathrm{g} / \mathrm{mL}$ & - & \\
\hline $\begin{array}{l}\text { Glutaryl ursolic } \\
\text { acid hemiester }\end{array}$ & & & & & $3 \mu \mathrm{g} / \mathrm{mL}$ & - & \\
\hline $\begin{array}{l}\text { Oxalyl ursolic } \\
\text { acid hemiester }\end{array}$ & & & & & $5 \mu \mathrm{g} / \mathrm{mL}$ & - & \\
\hline $\begin{array}{l}\text { Succinyl ursolic } \\
\text { acid hemiester }\end{array}$ & & & & & $10 \mu \mathrm{g} / \mathrm{mL}$ & - & \\
\hline $\begin{array}{l}\text { Ursolic acid } \\
\text { methyl ester }\end{array}$ & & & & & $94 \mu \mathrm{g} / \mathrm{mL}$ & - & \\
\hline Naringenin & & Flavanone & $\begin{array}{l}\text { Release/ } \\
\text { Assembly }\end{array}$ & $2 \mathrm{a}$ & - & - & $\begin{array}{l}{[74]} \\
{[110]}\end{array}$ \\
\hline Honokiol & & $\begin{array}{l}\text { Magnolia } \\
\text { officiais }\end{array}$ & $\begin{array}{l}\text { Entry/ } \\
\text { Replication }\end{array}$ & $1 a, 1 b, 2 a$ & $1.2 \mu \mathrm{M}$ & $35 \mu \mathrm{M}$ & [113] \\
\hline
\end{tabular}


Table 1 Plant-derived antivirals tested in cellular models with activity against HCV life cycle. Structures from PubChem (https:// pubchem.ncbi.nlm.nih.gov) (Continued)

\begin{tabular}{|c|c|c|c|c|c|c|c|}
\hline Compound & Structure & Extracted from & $\begin{array}{l}\text { Viral Inhibition } \\
\text { step }\end{array}$ & $\begin{array}{l}\text { HCV } \\
\text { genotypes }\end{array}$ & EC50 & CC50 & Reference \\
\hline Silymarin Extract & - & Silybum marianum & $\begin{array}{l}\text { Entry/ } \\
\text { Replication }\end{array}$ & $\begin{array}{l}2 a \\
1 a / 2 a \\
1 b, 3 a\end{array}$ & $\begin{array}{l}- \\
5 \mu \mathrm{M} \\
15 \pm 4 \mu \mathrm{M}\end{array}$ & - & $\begin{array}{l}131] \\
{[129]} \\
{[133]}\end{array}$ \\
\hline Silibinin & " & Silybum marianum & Entry & $1 b, 3 a$ & $34 \pm 3 \mu \mathrm{M}$ & - & [133] \\
\hline
\end{tabular}

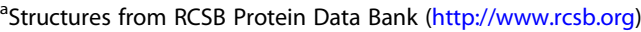

${ }^{\mathrm{b}}$ Structures from [93]

with infected Huh-7.5 in a dose-dependent manner. The results demonstrated the efficient blockage of virus entry with an approximate $\mathrm{IC}_{50}$ of $2.5 \mu \mathrm{g} / \mathrm{mL}$. To demonstrate whether EGCG can inhibit cell to cell spread the authors infected Huh-7.5 with HCVcc in the presence of EGCG and then co-cultured the infected cells with näive Huh-7.5 cells in an agarose overlay assay [124]. EGCG was added to the co-culture and no spread was observed during the treatment with EGCG at $3 \mu \mathrm{g} / \mathrm{mL}$ [125]. Calland et al. described EGCG acting on the early steps of virus entry by disrupting lipid metabolism in the host cells [121]. Recently, the same authors described that EGCG blocks virus infection $\left(\mathrm{EC}_{50}\right.$ of $\left.10.6 \pm 2.9 \mu \mathrm{M}\right)$ due to its action on $\mathrm{E} 1$ and $\mathrm{E} 2$ glycoproteins and induces conformational changes in the viral particles, a mechanism which affects the interaction between the viral particles and cell surface, as observed for delphinidin [55].

Chen et al. performed in vitro assays using the cell culture derivative JFH-1 HCV ( $\mathrm{HCVcc}$ ) system with GFP [126] and demonstrated that EGCG strongly decreased $\mathrm{HCV}$ infection $\left(\mathrm{EC}_{50}\right.$ of $\left.17.9 \mu \mathrm{M}\right)$ in a mechanism related to the virus entry inhibition. However, this group also observed a moderate action of EGCG on HCV replication. The authors used an HCV construct with an in-frame deletion in the HCV E1E2-coding sequence [127], to avoid reinfection. Huh-7.5.1 cells were treated with $80 \mu \mathrm{M}$ EGCG $4 \mathrm{~h}$ post transfection and the HCV RNA levels were measured $72 \mathrm{~h}$ later. The results showed that EGCG blocked $\mathrm{HCV}$ replication by the reduction of both the HCV RNA levels (66\%) and the expression of viral proteins NS3 and NS5A. The same inhibitory effect was also observed for HCV genotype 1b (Con-1 replicon) [128] (reduction of $56,6 \%$ of HCV RNA and a decrease of NS3 and NS5) [123]. Taken together this studies demonstrated the extraordinary potential of EGCG against HCV.

Silymarin is a mixture of silybin A, silybin B, isosilybin A, isosilybin B, silychristin, isosilychristin, and silydianin extracted from Silybum marianum (milk thistle). This extract has shown recently to block virus entry, RNA and protein expression, virus production and cell to cell spread of virus [129]. Additionally, this compound demonstrated a hepatoprotective effect on treated cells [130].
One of the major components of silymarin is silibinin, a mixture of semi-purified silybin A and silybin B and commercially available.

In 2007, Polyak et al., showed that silymarin was capable of blocking HCV infection using JFH1 [131] and also H77/JFH and J6/JFH systems [129]. The authors demonstrated that silymarin effect could be due to the inhibition of NS5B polymerase activity, although it did not seem to be the main mechanism of action of this compound.

Blaising et al. tested the purified compounds from silymarin extract silybin A, isosilybin A, silybin B, isosilybin B, silibinin, silychristin, taxifolin, isosilychristin and silydianin. The authors evaluated the antiviral activity of these compounds on $\mathrm{HCV}$ infection and demonstrated that silibinin is the main inhibitor of HCV fusion in silymarin extract. Using live-cell imaging studies in 3D-confocal microscopy, the authors observed the $\mathrm{HCV}$ intracellular trafficking into the host cells and demonstrated that silibinin blocked endosomal traffic in Huh-7.5. HCV entry in host cells is a complex processes which involves the presence of receptors CD81, OCLN, CLDN1 and SRB1 [29]. It is also associated with clathrin receptor that is related to clathrin-mediated endocytosis [30, 132]. Silibinin also inhibited $\mathrm{HCV}$ entry in primary human hepatocytes by hindering clathrin-mediated endocytosis and consequently viral entry [133].

\section{Future perspectives}

Most of the plant derived compounds cited in this review showed promising results in in vitro analysis (Table 1). However, some of the challenges in this field are the lack of in vivo studies, bioavailability and pharmacokinetics of plant derived compounds against HCV. In addition, some natural compounds were reported as Pan Assay INterference compoundS (PAINS), which may affect the results obtained by bioassays [134]. Compounds which possess these characteristics, such as quercetin and EGCG, need to be analyzed very carefully. Additionally, further analysis to confirm the effect of the compounds in vivo should be performed and also tests for obtaining the bioavailability and pharmacokinetics. According to the literature, the bioavailability of natural compounds is very diverse. The 
compounds Ladanein, after a single oral dose of $0.25 \mathrm{mg} /$ $\mathrm{kg}$, demonstrated a bioavailability of $329 \mathrm{nmol} / \mathrm{L}$ [52]. A pharmacokinetics study for $\mathrm{XN}$ demonstrated that the maximum XN concentrations were $45 \pm 7 \mu \mathrm{g} / \mathrm{L}, 67 \pm$ $11 \mu \mathrm{g} / \mathrm{L}$, and $133 \pm 23 \mu \mathrm{g} / \mathrm{L}$ for 20,60 , and $180 \mathrm{mg}$ oral dose, respectively [135]. Alternatives to improve the bioavailability of some natural compounds have been described with the advancement of nanotechnology [136], by improving the delivery of these compounds to their targets and raising the half-life of the compound within the body. However, there are only few studies on this topic by now.

\section{Conclusion}

In recent years, the standards treatments against hepatitis $\mathrm{C}$ have shown several improvements. However, many issues remain unsolved, as the prevalence of resistance associated variants to DAAs. Natural products represent an increasing source in development of new drugs and could either improve the DAAs treatment or provide alternative approaches in the HCV treatment. Several plant-derived compounds have shown effectiveness against $\mathrm{HCV}$ and the improvement on the HCV assay systems allows a better evaluation of the antiviral activity of compounds act on HCV life cycle. However, many mechanisms of action of active compounds remain unknown. Considering the current worldwide biodiversity there may be many plantderived products to be discovered by their antiviral actions.

\section{Abbreviations \\ 3-HCL-C: 3-hydroxy caruilignan C; ALT: Alanine aminotransferase; CLDN1: Claudin 1; DAAs: Direct-acting antivirals; DGAT1: Diacyglycerol acyltransferase-1; EGCG: Epigallocatechin-3-gallate; ER: Endoplasmic reticulum; FDA: Food and Drug Administration; GA: Gallic acid; GRFT: Griffithsin; HCV: Hepatitis C virus; HSP: Heat shock proteins; IFN: Interferon; IRES: Internal ribosome entry site; LDL: Low density lipoproteins; LS-UW: Limonium sinense aqueous extract; LXR: Liver X receptor; MG-EtOH: Mangosteen frit peels; miR122: MicroRNA122; MTP: Microsomal triglyceride transfer protein; OCLN: Occludin; PAINS: Pan Assay Interference Compounds; RBV: ribavirin; ROS/ SNS: Oxidative/nitrosative stress; SRB1: Scavenger receptor class B type 1; SVN: Scytovirin; UTR: Untranslated regions; VLDL: Very low density lipoproteins}

\section{Acknowledgements}

Not applicable.

\section{Funding}

CNPQ (National Counsel of Technological and Scientific Development grant 445021/2014-4), FAPEMIG (Minas Gerais Research Foundation - APQ00587-14), Royal Society - Newton Advanced Fellowship (grant reference NA 150195), Wellcome Trust Investigator Award (grant reference 096670).

\section{Availability of data and materials}

Data sharing is not applicable to this article as no datasets were generated or analysed during the current study.

\section{Authors' contributions}

ACGJ and JFS: Drafting the manuscript and literature review. $\mathrm{MH}$ and PR: critical revision and editing, and final approval of the final version. All the authors read and approved the final manuscript.

Ethics approval and consent to participate Not applicable.
Consent for publication

Not applicable.

\section{Competing interests}

The authors declare that they have no competing interests.

\section{Publisher's Note}

Springer Nature remains neutral with regard to jurisdictional claims in published maps and institutional affiliations.

\section{Author details}

${ }^{1}$ Laboratory of Virology, Institute of Biomedical Science, ICBIM, Federal University of Uberlândia, Avenida Amazonas, Bloco 4C - sala 216. Umuarama, Uberlândia, MG CEP: 38405-302, Brazil. ${ }^{2}$ Genomics Study Laboratory, São Paulo State University, São José do Rio Preto, SP, Brazil. ${ }^{3}$ School of Molecular and Cellular Biology, Faculty of Biological Sciences and Astbury Centre for Structural Molecular Biology, University of Leeds, Leeds LS2 9JT, UK.

Received: 26 October 2017 Accepted: 2 February 2018

Published online: 13 February 2018

\section{References}

1. Shepard CW, Finelli L, Alter MJ. Global epidemiology of hepatitis C virus infection. Lancet Infect Dis. 2005;5:558-67.

2. Munir S, Saleem S, Idrees M, Tariq A, Butt S, Rauff B, et al. Hepatitis C treatment: current and future perspectives. Virol J. 2010;7:296.

3. Thomas DL. Global. Control of hepatitis C: where challenge meets opportunity. Nat. Med. Nat Publ Group. 2013;19:850-8.

4. Nelson PK, Mathers BM, Cowie B, Hagan H, Des Jarlais D, Horyniak D, et al. Global epidemiology of hepatitis B and hepatitis $C$ in people who inject drugs: results of systematic reviews. Lancet. 2011;378:571-83.

5. World Health Organization. WHO guideline on the use of safety-engineered syringes for intramuscular, intradermal and subcutaneous injections in health-care settings. 2015;1-32.

6. WHO | Hepatitis C [Internet]. WHO. World Health Organization; 2017 [cited 2017 Dec 28]. Available from: http://www.who.int/mediacentre/factsheets/ fs164/en/

7. Fried MW, Shiffman ML, Reddy KR, Smith C, Marinos G, Gonçales FL, et al. Peginterferon alfa-2a plus ribavirin for chronic hepatitis $C$ virus infection. N Engl J Med. 2002;347:975-82.

8. Hadziyannis SJ, Sette H, Morgan TR, Balan V, Diago M, Marcellin P, et al. Peginterferon-alpha2a and ribavirin combination therapy in chronic hepatitis $C$ : a randomized study of treatment duration and ribavirin dose. Ann Intern Med. 2004;140:346-55.

9. Manns MP, McHutchison JG, Gordon SC, Rustgi VK, Shiffman M, Reindollar R, et al. Peginterferon alfa-2b plus ribavirin compared with interferon alfa- $2 \mathrm{~b}$ plus ribavirin for initial treatment of chronic hepatitis C: a randomised trial. Lancet. 2001;

10. Pawlotsky J-M. New hepatitis C therapies: the toolbox, strategies, and challenges. Gastroenterology. 2014;146:1176-92.

11. Pawlotsky J-M. New hepatitis C virus ( $\mathrm{HCV}$ ) drugs and the hope for a cure: concepts in anti-HCV drug development. Semin Liver Dis. 2014;34:22-9.

12. Kotwal GJ. Natural Antivirals against Human Viruses. Virol. Mycol. 2014;3

13. De Clercq E. Highlights In antiviral drug research: antivirals at the horizon. Med Res Rev. 2013;33:1215-48.

14. Calland N, Dubuisson J, Rouillé Y, Séron K. Hepatitis C virus and natural compounds: a new antiviral approach? Viruses. Inserm U1019, CNRS UMR8204, Center for Infection \& Immunity of Lille (CIIL), Institut Pasteur de Lille, Université Lille Nord de France, Lille, France. karin.seron@ibl.fr.; 2012;4: 2197-217.

15. Assini JM, Mulvihill EE, Burke AC, Sutherland BG, Telford DE, Chhoker SS, et al. Naringenin prevents obesity, hepatic steatosis, and glucose intolerance in male mice independent of fibroblast growth factor 21. Endocrinology. 2015; 156:2087-102.

16. Tipoe GL, Leung TM, Liong EC, Lau TYH, Fung ML, Nanji AA. Epigallocatechin-3-gallate (EGCG) reduces liver inflammation, oxidative stress and fibrosis in carbon tetrachloride (CCl4)-induced liver injury in mice. Toxicology. 2010;273:45-52.

17. W. Z, R. H. Silymarin's protective effects and possible mechanisms on alcoholic fatty liver for rats. Biomol Ther 2013;21:264-269. 
18. Khalaf N, White D, Kanwal F, Ramsey D, Mittal S, Tavakoli-Tabasi S, et al. Coffee and caffeine are associated with decreased risk of advanced hepatic fibrosis among patients with hepatitis C. Clin Gastroenterol Hepatol. 2015;13:1521-1531.e3.

19. Kitazato K, Wang Y, Kobayashi N. Viral infectious disease and natural products with antiviral activity. Drug Discov Ther. 2007;1:14-22.

20. Mann J. Natural products in cancer chemotherapy: past, present and future. Nat Rev Cancer. 2002;2:143-8.

21. Balunas M, Kinghorn A. Drug discovery from medicinal plants. Life Sci. Program for Collaborative Research in the Pharmaceutical Sciences, Department of Medicinal Chemistry and Pharmacognosy, College of Pharmacy, 833 South Wood Street, University of Illinois at Chicago, Chicago, IL 60612, USA.; 2005;78:431-41.

22. Brahmachari G. Natural Products in Drug Discovery: Impacts and Opportunities - An Assessment. Bioact. Nat. Prod. WORLD SCIENTIFIC; 2011. p. 1-199.

23. Simmonds $P$. The origin of hepatitis $C$ virus. Curr Top Microbiol Immunol. 2013;369:1-15

24. Murakami K, Abe M, Kageyama T, Kamoshita N, Nomoto A. Down-regulation of translation driven by hepatitis $C$ virus internal ribosomal entry site by the 3' untranslated region of RNA. Arch Virol. 2001;146:729-41.

25. Friebe $P$, Lohmann V, Krieger N, Bartenschlager R. Sequences in the $5^{\prime}$ nontranslated region of hepatitis $C$ virus required for RNA replication. J Virol. 2001;75:12047-57

26. André $P$, Komurian-Pradel $F$, Deforges $S$, Perret $M$, Berland JL, Sodoyer $M$, et al. Characterization of low- and very-low-density hepatitis C virus RNAcontaining particles. J Virol. 2002;76:6919-28.

27. Bartenschlager R, Penin F, Lohmann V, André P. Assembly of infectious hepatitis C virus particles. Trends Microbiol Elsevier Trends Journals. 2011;19:95-103.

28. Lindenbach BD. Virion Assembly and Release. In: Bartenschlager R, editor. Curr. Top. Microbiol. Immunol. Berlin, Heidelberg: Springer Berlin Heidelberg; 2013. p. 199-218.

29. Zeisel MB, Felmlee DJ, Baumert TF. Hepatitis C virus entry. Curr Top Microbiol Immunol. 2013:369:87-112.

30. Blanchard E, Belouzard S, Goueslain L, Wakita T, Dubuisson J, Wychowski C, et al. Hepatitis C virus entry depends on Clathrin-mediated endocytosis. J Virol. 2006;80:6964-72.

31. Rupp D, Bartenschlager R. Targets for antiviral therapy of hepatitis C. Semin Liver Dis. 2014;34:9-21.

32. Moradpour D, Penin F, Hepatitis C. Virus proteins: from structure to function Curr Top Microbiol Immunol. 2013;369:113-42.

33. Ait-Goughoulte M. Core protein cleavage by signal peptide peptidase is required for hepatitis C virus-like particle assembly. J Gen Virol. 2006;87:855-60.

34. Egger D, Wolk B, Gosert R, Bianchi L, Blum HE, Moradpour D, et al. Expression of hepatitis $C$ virus proteins induces distinct membrane alterations including a candidate viral replication complex. J Virol. 2002;76:5974-84.

35. Moradpour D, Gosert R, Egger D, Penin F, Blum HE, Bienz K. Membrane association of hepatitis $C$ virus nonstructural proteins and identification of the membrane alteration that harbors the viral replication complex. Antivi Res. 2003:60:103-9.

36. Gosert R, Egger D, Lohmann V, Bartenschlager R, Blum HE, Bienz K, et al. Identification of the hepatitis $C$ virus RNA replication complex in huh-7 cells harboring subgenomic replicons. J Virol. 2003;77:5487-92.

37. Fournier C, Hoffmann TW, Morel V, Descamps V, Dubuisson J, Brochot E, et al. Claudin-1, miR-122 and apolipoprotein E transductions improve the permissivity of SNU-182, SNU-398 and SNU-449 hepatoma cells to hepatitis C virus. J Viral Hepat. 2017;

38. Mankouri J, Walter C, Stewart H, Bentham M, Park WS, Heo W. Do, et al. release of infectious hepatitis $C$ virus from Huh7 cells occurs via a Trans -Golgi network-to-endosome pathway independent of very-low-density lipoprotein secretion. Diamond MS. J Virol. 2016;90:7159-70.

39. Lindenbach BD, Rice CM. The ins and outs of hepatitis $C$ virus entry and assembly. Nat Rev Micro. Nature Publishing Group, a division of Macmillan Publishers Limited. All Rights Reserved.; 2013;11:688-700.

40. Boulant S, Montserret R, Hope RG, Ratinier M, Targett-Adams P, Lavergne J$P$, et al. Structural determinants that target the hepatitis $C$ virus core protein to lipid droplets. J Biol Chem. 2006;281:22236-47.

41. Roingeard P, Dreneau J, Meunier J-C. Unravelling the multiple roles of apolipoprotein E in the hepatitis C virus life cycle. Gut. 2017:66:759-61.

42. Vieyres G, Thomas X, Descamps V, Duverlie G, Patel AH, Dubuisson J. Characterization of the envelope glycoproteins associated with infectious hepatitis C virus. J Virol. 2010;84:10159-68.
43. Mori T, O'Keefe BR, Sowder RC, Bringans S, Gardella R, Berg S, et al. Isolation and characterization of griffithsin, a novel HIV-inactivating protein, from the red alga Griffithsia sp. J Biol Chem. 2005;280:9345-53.

44. Bokesch HR, O'Keefe BR, McKee TC, Pannell LK, Patterson GML, Gardella RS, et al. A potent novel anti-HIV protein from the cultured cyanobacterium Scytonema Varium. Biochemistry. 2003;42:2578-84.

45. Takebe Y, Saucedo CJ, Lund G, Uenishi R, Hase S, Tsuchiura T, et al. Antiviral lectins from red and blue-green algae show potent in vitro and in vivo activity against hepatitis C virus. Choi J. PLoS One. 2013;8:1-10.

46. McFeeters RL, Xiong C, O'Keefe BR, Bokesch HR, McMahon JB, Ratner DM, et al. The novel fold of scytovirin reveals a new twist for antiviral entry inhibitors. J Mol Biol. 2007;369:451-61.

47. Moulaei T, Botos I, Ziółkowska NE, Bokesch HR, Krumpe LR, McKee TC, et al. Atomic-resolution crystal structure of the antiviral lectin scytovirin. Protein Sci. 2007:16:2756-60

48. Ziółkowska NE, O’Keefe BR, Mori T, Zhu C, Giomarelli B, Vojdani F, et al. Domain-swapped structure of the potent antiviral protein griffithsin and its mode of carbohydrate binding. Structure. 2006;14:1127-35.

49. Hsu W-C, Chang S-P, Lin L-C, Li C-L, Richardson CD, Lin C-C, et al. Limonium Sinense and gallic acid suppress hepatitis $C$ virus infection by blocking early viral entry. Antiviral Res. Elsevier B.V. 2015;118:139-47.

50. Lin L-T, Chung C-Y, Hsu W-C, Chang S-P, Hung T-C, Shields J, et al. Saikosaponin b2 is a naturally occurring terpenoid that efficiently inhibits hepatitis C virus entry. J Hepatol. 2015;62:541-8.

51. Fan J, Li X, Li P, Li N, Wang T, Shen H, et al. Saikosaponin-d attenuates the development of liver fibrosis by preventing hepatocyte injury. Biochem Cell Biol. 2007:85:189-95.

52. Haid S, Novodomská A, Gentzsch J, Grethe C, Geuenich S, Bankwitz D, et al. A plant-derived flavonoid inhibits entry of all HCV genotypes into human hepatocytes. Gastroenterology. 2012;143:213-222.e5.

53. Grove J, Nielsen S, Zhong J, Bassendine MF, Drummer HE, Balfe P, et al. Identification of a residue in hepatitis $C$ virus $E 2$ glycoprotein that determines scavenger receptor $\mathrm{BI}$ and CD81 receptor dependency and sensitivity to neutralizing antibodies. J Virol. 2008;82:12020-9.

54. Syder AJ, Lee H, Zeisel MB, Grove J, Soulier E, Macdonald J, et al. Small molecule scavenger receptor $\mathrm{Bl}$ antagonists are potent $\mathrm{HCV}$ entry inhibitors. J Hepatol. 2011;54:48-55

55. Calland N, Sahuc M-E, Belouzard S, Pène $V$, Bonnafous $P$, Mesalam AA, et al. Polyphenols inhibit hepatitis $C$ virus entry by a new mechanism of action. Diamond MS. J Virol. 2015;89:10053-63.

56. Choi M, Kim Y-M, Lee S, Chin Y-W, Lee C. Mangosteen xanthones suppress hepatitis C virus genome replication. Virus Genes. 2014;49:208-22.

57. Gao M, Nettles RE, Belema M, Snyder LB, Nguyen VN, Fridell RA, et al. Chemical genetics strategy identifies an HCV NS5A inhibitor with a potent clinical effect. Nature. 2010;465:96-100.

58. Wu S-F, Lin C-K, Chuang Y-S, Chang F-R, Tseng C-K, Wu Y-C, et al. Antihepatitis $C$ virus activity of 3-hydroxy caruilignan C from Swietenia Macrophylla stems. J Viral Hepat. 2012;19:364-70.

59. Sakunrangsit N, Kalpongnukul N, Pisitkun T, Ketchart W. Plumbagin enhances tamoxifen sensitivity and inhibits tumor invasion in endocrine resistant breast cancer through EMT regulation. Phyther Res. 2016;

60. Wang T, Wu F, Jin Z, Zhai Z, Wang Y, Tu B, et al. Plumbagin inhibits LPSinduced inflammation through the inactivation of the nuclear factor-kappa $B$ and mitogen activated protein kinase signaling pathways in RAW 264. 7 cells. Food Chem Toxicol Elsevier Ltd. 2014;64:177-83.

61. Hassan STS, Berchová-Bímová K, PetráŠ J. Plumbagin, a plant-derived compound, exhibits antifungal combinatory effect with amphotericin B against Candida Albicans clinical isolates and anti-hepatitis $C$ virus activity. Phyther. Res. 2016;30:1487-92.

62. Zhu Y-P, Peng Z-G. Wu Z-Y, li J-R, Huang M-H, Si S-Y, et al. host APOBEC3G protein inhibits HCV replication through direct binding at NS3. Villa E. PLoS One. 2015;10:e0121608.

63. Stevens JF, Taylor AW, Deinzer ML. Quantitative analysis of xanthohumol and related prenylflavonoids in hops and beer by liquid chromatographytandem mass spectrometry. J Chromatogr A. 1999;832:97-107.

64. Stevens JF, Taylor AW, Clawson JE, Deinzer ML. Fate of xanthohumol and related prenylflavonoids from hops to beer. J Agric Food Chem. 1999;47: 2421-8.

65. Gerhauser C, Alt A, Heiss E, Gamal-Eldeen A, Klimo K, Knauft J, et al. Cancer chemopreventive activity of Xanthohumol, a natural product derived from hop. Mol Cancer Ther. 2002;1:959-69. 
66. Cho Y-C, Kim HJ, Kim Y-J, Lee KY, Choi HJ, Lee I-S, et al. Differential antiinflammatory pathway by xanthohumol in IFN-gamma and LPS-activated macrophages. Int Immunopharmacol. 2008;8:567-73.

67. Peluso MR, Miranda CL, Hobbs DJ, Proteau RR, Stevens JF. Xanthohumol and related prenylated flavonoids inhibit inflammatory cytokine production in LPSactivated THP-1 monocytes: structure-activity relationships and in silico binding to myeloid differentiation protein-2 (MD-2). Planta Med. 2010;76:1536-43.

68. Zhang N, Liu Z, Han Q, Chen J, Lv Y. Xanthohumol enhances antiviral effect of interferon alpha-2b against bovine viral diarrhea virus, a surrogate of hepatitis C virus. Phytomedicine. 2010;17:310-6.

69. Zhang N, Liu Z, Han Q, Chen J, Lou S, Qiu J, et al. Inhibition of bovine viral diarrhea virus in vitro by xanthohumol: comparisons with ribavirin and interferon-alpha and implications for the development of anti-hepatitis C virus agents. Eur J Pharm Sci. 2009;38:332-40.

70. Buckwold VE, Wilson RJH, Nalca A, Beer BB, Voss TG, Turpin JA, et al. Antiviral activity of hop constituents against a series of DNA and RNA viruses. Antivir Res. 2004;61:57-62.

71. Lou S, Zheng Y-M, Liu S-L, Qiu J, Han Q, Li N, et al. Inhibition of hepatitis C virus replication in vitro by Xanthohumol, a natural product present in hops. Planta Med. 2013;80:171-6.

72. Casaschi A, Maiyoh GK, Rubio BK, Li RW, Adeli K, Theriault AG. The chalcone xanthohumol inhibits triglyceride and apolipoprotein B secretion in HepG2 cells. J Nutr. 2004;134:1340-6.

73. Herker E, Harris C, Hernandez C, Carpentier A, Kaehlcke K, Rosenberg AR, et al. Efficient hepatitis $C$ virus particle formation requires diacylglycerol acyltransferase-1. Nat Med. 2010;16:1295-8.

74. Nahmias Y, Goldwasser J, Casali M, van Poll D, Wakita T, Chung RT, et al. Apolipoprotein B-dependent hepatitis $C$ virus secretion is inhibited by the grapefruit flavonoid naringenin. Hepatology. 2008;47:1437-45.

75. Yang M, Li N, Li F, Zhu Q, Liu X, Han Q, et al. Xanthohumol, a main prenylated chalcone from hops, reduces liver damage and modulates oxidative reaction and apoptosis in hepatitis $C$ virus infected Tupaia Belangeri. Int Immunopharmacol. 2013;16:466-74.

76. Chan L-P, Chou T-H, Ding H-Y, Chen P-R, Chiang F-Y, Kuo P-L, et al. Apigenin induces apoptosis via tumor necrosis factor receptor- and Bcl-2-mediated pathway and enhances susceptibility of head and neck squamous cell carcinoma to 5-fluorouracil and cisplatin. Biochim Biophys Acta. 2012;1820:1081-91.

77. Mafuvadze B, Liang Y, Besch-Williford C, Zhang X, Hyder SM. Apigenin induces apoptosis and blocks growth of medroxyprogesterone acetatedependent BT-474 xenograft tumors. Horm Cancer. 2012;3:160-71.

78. Shukla S, MacLennan GT, Flask CA, Fu P, Mishra A, Resnick Ml, et al. Blockade of beta-catenin signaling by plant flavonoid apigenin suppresses prostate carcinogenesis in TRAMP mice. Cancer Res. 2007;67:6925-35.

79. Nicholas C, Batra S, Vargo MA, Voss OH, Gavrilin MA, Wewers MD, et al. Apigenin blocks lipopolysaccharide-induced lethality in vivo and proinflammatory cytokines expression by inactivating NF-kappaB through the suppression of p65 phosphorylation. J Immunol. 2007;179:7121-7.

80. Landolfi R, Mower RL, Steiner M. Modification of platelet function and arachidonic acid metabolism by bioflavonoids. Structure-activity relations Biochem Pharmacol. 1984;33:1525-30.

81. Ohno M, Shibata C, Kishikawa T, Yoshikawa T, Takata A, Kojima K, et al. The flavonoid apigenin improves glucose tolerance through inhibition of microRNA maturation in miRNA103 transgenic mice. Sci Rep. 2013;3:2553.

82. Jopling CL, Yi M, Lancaster AM, Lemon SM, Sarnow P. Modulation of hepatitis C virus RNA abundance by a liver-specific MicroRNA. Science. 2005;309:1577-81.

83. Pfeffer S, Baumert TF. Impact of microRNAs for pathogenesis and treatment of hepatitis C virus infection. Gastroentérologie Clin Biol. 2010;34:431-5.

84. Shibata C, Ohno M, Otsuka M, Kishikawa T, Goto K, Muroyama R, et al. The flavonoid apigenin inhibits hepatitis $C$ virus replication by decreasing mature microRNA122 levels. Virology Elsevier. 2014;462-463:42-8.

85. Freedman ND, Everhart JE, Lindsay KL, Ghany MG, Curto TM, Shiffman ML, et al. Coffee intake is associated with lower rates of liver disease progression in chronic hepatitis C. Hepatology. 2009;50:1360-9.

86. Inoue M, Kurahashi N, Iwasaki M, Shimazu T, Tanaka Y, Mizokami M, et al. Effect of coffee and green tea consumption on the risk of liver cancer: cohort analysis by hepatitis virus infection status. Cancer Epidemiol Biomark Prev. 2009;18:1746-53.

87. Molloy JW, Calcagno CJ, Williams CD, Jones FJ, Torres DM, Harrison SA. Association of coffee and caffeine consumption with fatty liver disease, nonalcoholic steatohepatitis, and degree of hepatic fibrosis. Hepatology. 2012:55:429-36
88. Costentin CE, Roudot-Thoraval F, Zafrani E-S, Medkour F, Pawlotsky J-M, Mallat $A$, et al. Association of caffeine intake and histological features of chronic hepatitis C. J Hepatol. 2011;54:1123-9.

89. Okano J, Nagahara T, Matsumoto K, Murawaki Y. Caffeine inhibits the proliferation of liver cancer cells and activates the MEK/ERK/EGFR signalling pathway. Basic Clin Pharmacol Toxicol. 2008;102:543-51.

90. Modi AA, Feld JJ, Park Y, Kleiner DE, Everhart JE, Liang TJ, et al. Increased caffeine consumption is associated with reduced hepatic fibrosis. Hepatology. 2010;51:201-9.

91. Ruhl CE, Everhart JE. Coffee and caffeine consumption reduce the risk of elevated serum alanine aminotransferase activity in the United States. Gastroenterology. 2005;128:24-32.

92. Batista MN, Carneiro BM, Braga ACS, Rahal P. Caffeine inhibits hepatitis C virus replication in vitro. Arch Virol. 2015;160:399-407.

93. Jardim ACG, Igloi Z, Shimizu JF, Santos VAFFM, Felippe LG, Mazzeu BF, et al. Natural compounds isolated from Brazilian plants are potent inhibitors of hepatitis C virus replication in vitro. Antiviral Res Elsevier BV. 2015;115:39-47.

94. Lemm JA, O'Boyle D, Liu M, Nower PT, Colonno R, Deshpande MS, et al. Identification of hepatitis C virus NS5A inhibitors. J Virol. 2010;84:482-91.

95. Guedj J, Dahari H, Rong L, Sansone ND, Nettles RE, Cotler SJ, et al. Modeling shows that the NS5A inhibitor daclatasvir has two modes of action and yields a shorter estimate of the hepatitis C virus half-life. Proc Natl Acad Sci U S A. 2013;110:3991-6.

96. Miean $\mathrm{KH}$, Mohamed S. Flavonoid (myricetin, quercetin, kaempferol, luteolin, and apigenin) content of edible tropical plants. J Agric Food Chem. 2001;49:3106-12.

97. Gonzalez O, Fontanes V, Raychaudhuri S, Loo R, Loo J, Arumugaswami V, et al. The heat shock protein inhibitor quercetin attenuates hepatitis $C$ virus production. Hepatology. 2009;50:1756-64.

98. Khachatoorian R, Arumugaswami V, Ruchala P, Raychaudhuri S, Maloney EM,

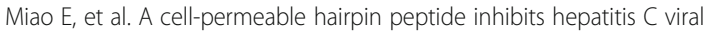
nonstructural protein 5A-mediated translation and virus production. Hepatology. 2012;55:1662-72.

99. Bachmetov L, Gal-Tanamy M, Shapira A, Vorobeychik M, Giterman-Galam T, Sathiyamoorthy $P$, et al. Suppression of hepatitis $C$ virus by the flavonoid quercetin is mediated by inhibition of NS3 protease activity. J Viral Hepat. 2012;19:e81-8.

100. Pisonero-Vaquero S, García-Mediavilla MV, Jorquera F, Majano PL, Benet M, Jover R, et al. Modulation of PI3K-LXRa-dependent lipogenesis mediated by oxidative/nitrosative stress contributes to inhibition of HCV replication by quercetin. Lab Investig. 2014;94:262-74.

101. Sajitha Lulu S, Thabitha A, Vino S, Mohana Priya A, Rout M. Naringenin and quercetin - potential anti-HCV agents for NS2 protease targets. Nat Prod Res. 2016;30:464-8.

102. Ma C-M, Wei Y, Wang Z-G, Hattori M. Triterpenes from Cynomorium songaricium — analysis of HCV protease inhibitory activity, quantification, and content change under the influence of heating. J Nat Med. 2009;63:9-14.

103. Wilcox LJ, Borradaile NM, Huff MW. Antiatherogenic properties of Naringenin, a citrus flavonoid. Cardiovasc Drug Rev. 2006;17:160-78.

104. Kanno S-I, Tomizawa A, Hiura T, Osanai Y, Shouji A, Ujibe M, et al. Inhibitory effects of naringenin on tumor growth in human cancer cell lines and sarcoma S-180-implanted mice. Biol Pharm Bull. 2005;28:527-30.

105. Moon YJ, Wang X, Morris ME. Dietary flavonoids: effects on xenobiotic and carcinogen metabolism. Toxicol in Vitro. 2006;20:187-210.

106. Allister EM, Borradaile NM, Edwards JY, Huff MW. Inhibition of microsomal triglyceride transfer protein expression and apolipoprotein B100 secretion by the citrus flavonoid naringenin and by insulin involves activation of the mitogenactivated protein kinase pathway in hepatocytes. Diabetes. 2005;54:1676-83.

107. Kurowska EM, Borradaile NM, Spence JD, Carroll KK. Hypocholesterolemic effects of dietary citrus juices in rabbits. Nutr Res. 2000;20:121-9.

108. Jung UJ, Kim HJ, Lee JS, Lee MK, Kim HO, Park EJ, et al. Naringin supplementation lowers plasma lipids and enhances erythrocyte antioxidant enzyme activities in hypercholesterolemic subjects. Clin Nutr. 2003;22:561-8.

109. Kurowska EM, Spence JD, Jordan J, Wetmore S, Freeman DJ, Piché LA, et al. $\mathrm{HDL}$-cholesterol-raising effect of orange juice in subjects with hypercholesterolemia. Am J Clin Nutr. 2000;72:1095-100.

110. Goldwasser J, Cohen PY, Lin W, Kitsberg D, Balaguer P, Polyak SJ, et al. Naringenin inhibits the assembly and long-term production of infectious hepatitis $C$ virus particles through a PPAR-mediated mechanism. J. Hepatol. European Association for the Study of the. Liver. 2011;55:963-71.

111. Spann NJ, Kang S, Li AC, Chen AZ, Newberry EP, Davidson NO, et al. Coordinate transcriptional repression of liver fatty acid-binding protein and microsomal triglyceride transfer protein blocks hepatic very low density lipoprotein secretion without hepatosteatosis. J Biol Chem. 2006;281:33066-77. 
112. Jones CT, Murray CL, Eastman DK, Tassello J, Rice CM. Hepatitis C virus p7 and NS2 proteins are essential for production of infectious virus. J Virol. 2007:81:8374-83.

113. Lan K-H, Wang Y-W, Lee W-P, Lan K-L, Tseng S-H, Hung L-R, et al. Multiple effects of Honokiol on the life cycle of hepatitis C virus. Liver Int. 2012;32:989-97.

114. Chen Y, Li J, Zeng M, Lu L, Qu D, Mao Y, et al. TThe inhibitory effect of oxymatrine on hepatitis C virus in vitro]. Zhonghua Gan Zang Bing Za Zhi. 2001;9 Suppl:12-4

115. Liu J, Liu Y, Klaassen CD. The effect of Chinese hepatoprotective medicines on experimental liver injury in mice. J Ethnopharmacol. 1994;42:183-91.

116. Azzam HS, Goertz C, Fritts M, Jonas WB. Natural products and chronic hepatitis C virus. Liver Int. 2007;27:17-25.

117. Hussein G, Miyashiro H, Nakamura N, Hattori M, Kakiuchi N, Shimotohno K. Inhibitory effects of sudanese medicinal plant extracts on hepatitis $C$ virus (HCV) protease. Phytother Res. 2000;14:510-6.

118. Mao Y-M, Zeng M-D, Lu L-G, Wan M-B, Li C-Z, Chen C-W, et al. Capsule oxymatrine in treatment of hepatic fibrosis due to chronic viral hepatitis: a randomized, double blind, placebo-controlled, multicenter clinical study. World J Gastroenterol. 2004;10:3269-73.

119. Weber C, Sliva K, von Rhein C, Kümmerer BM, Schnierle BS. The green tea catechin, epigallocatechin gallate inhibits chikungunya virus infection. Antivir Res. 2015;113:1-3.

120. Ho H-Y, Cheng M-L, Weng S-F, Leu Y-L, Chiu DT-Y. Antiviral effect of epigallocatechin Gallate on enterovirus 71. J Agric Food Chem. 2009;57:6140-7.

121. Calland N, Albecka A, Belouzard S, Wychowski C, Duverlie G, Descamps V, et al. (-)-Epigallocatechin-3-gallate is a new inhibitor of hepatitis $C$ virus entry. Hepatology. 2012;55:720-9.

122. Gao Z, Han Y. Hu Y, Wu X, Wang Y, Zhang X, et al. targeting HO-1 by Epigallocatechin-3-Gallate reduces contrast-induced renal injury via antioxidative stress and anti-inflammation pathways. PLoS one. Public Libr Sci. 2016;11:e0149032

123. Chen C, Qiu H, Gong J, Liu Q, Xiao H, Chen XW, et al. (-)-Epigallocatechin-3gallate inhibits the replication cycle of hepatitis C virus. Arch Virol. 2012;157: 1301-12.

124. Ciesek S, Westhaus S, Wicht M, Wappler I, Henschen S, Sarrazin C, et al. Impact of intra- and interspecies variation of occludin on its function as coreceptor for authentic hepatitis C virus particles. J Virol. 2011;85:7613-21.

125. Ciesek S, von Hahn T, Colpitts CC, Schang LM, Friesland M, Steinmann J, et al. The green tea polyphenol, epigallocatechin-3-gallate, inhibits hepatitis C virus entry. Hepatology. 2011;54:1947-55.

126. Han Q, Xu C, Wu C, Zhu W, Yang R, Chen X. Compensatory mutations in NS3 and NS5A proteins enhance the virus production capability of hepatitis C reporter virus. Virus Res. 2009;145:63-73.

127. Wakita T, Pietschmann T, Kato T, Date T, Miyamoto M, Zhao Z, et al Production of infectious hepatitis $C$ virus in tissue culture from a cloned viral genome. Nat Med. 2005;11:791-6.

128. Lohmann V, Körner F, Koch J, Herian U, Theilmann L, Bartenschlager R Replication of subgenomic hepatitis C virus RNAs in a hepatoma cell line. Science. 1999;285:110-3.

129. Wagoner J, Negash A, Kane OJ, Martinez LE, Nahmias Y, Bourne N, et al. Multiple effects of silymarin on the hepatitis C virus lifecycle. Hepatology. 2010;51:1912-21.

130. Polyak SJ, Morishima C, Lohmann V, Pal S, Lee DYW, Liu Y, et al. Identification of hepatoprotective flavonolignans from silymarin. Proc Natl Acad Sci U S A. 2010;107:5995-9.

131. Polyak SJ, Morishima C, Shuhart MC, Wang CC, Liu Y, Lee DYW. Inhibition of T-cell inflammatory cytokines, hepatocyte NF-kB signaling, and HCV infection by standardized Silymarin. Gastroenterology. 2007;132:1925-36.

132. Bartenschlager R, Lohmann V, Penin F. The molecular and structural basis of advanced antiviral therapy for hepatitis $C$ virus infection. Nat Rev Microbiol. 2013;11:482-96

133. Blaising J, Lévy PL, Gondeau C, Phelip C, Varbanov M, Teissier E, et al. Silibinin inhibits hepatitis $C$ virus entry into hepatocytes by hindering clathrin-dependent trafficking. Cell Microbiol. 2013;15:1866-82.

134. Baell JB. Feeling Nature's PAINS: natural products, natural product drugs, and pan assay Interference compounds (PAINS). J Nat Prod. 2016;79:616-28.

135. Legette L, Karnpracha C, Reed RL, Choi J, Bobe G, Christensen JM, et al. Human pharmacokinetics of xanthohumol, an antihyperglycemic flavonoid from hops. Mol Nutr Food Res. 2014;58:248-55.

136. Lin C-H, Chen C-H, Lin Z-C, Fang J-Y. Recent advances in oral delivery of drugs and bioactive natural products using solid lipid nanoparticles as the carriers. J Food Drug Anal Elsevier Ltd. 2017;25:219-34.

\section{Submit your next manuscript to BioMed Central and we will help you at every step:}

- We accept pre-submission inquiries

- Our selector tool helps you to find the most relevant journal

- We provide round the clock customer support

- Convenient online submission

- Thorough peer review

- Inclusion in PubMed and all major indexing services

- Maximum visibility for your research

Submit your manuscript at www.biomedcentral.com/submit 